\title{
NUTRIENT CYCLING IN A RRIM 600 CLONE RUBBER PLANTATION
}

\author{
Marcos Roberto Murbach ${ }^{1,5}$; Antonio Enedi Boaretto ${ }^{2,6 *}$; Takashi Muraoka ${ }^{3,6}$; Euclides Caxambu \\ Alexandrino de Souza ${ }^{4}$ \\ ${ }^{1}$ UNESP/FCAV - Depto. de Produção Vegetal, Via de Acesso Prof. Paulo Donato Castelani, s/n, - 14884-900 - \\ Jaboticabal, SP - Brasil. \\ ${ }_{3}^{2}$ USP/CENA - Lab. de Nutrição Mineral de Plantas, C.P. 96 - 13400-970 - Piracicaba, SP - Brasil. \\ ${ }^{3}$ USP/CENA - Lab. de Fertilidade do Solo. \\ ${ }_{5}^{4} U N E S P / F C A V$ - Depto. de Solos e Adubos. \\ ${ }^{5}$ FAPESP scholar. \\ ${ }^{6} \mathrm{CNPq}$ scholar. \\ *Corresponding author <aeboaret@cena.usp.br>
}

\begin{abstract}
Few reports have been presented on nutrient cycling in rubber tree plantations (Hevea brasiliensis Muell. Arg.). This experiment was carried out to evaluate: the effect of K rates on the amount of nutrients transfered to the soil in a 13-year old Hevea brasilensis RRIM 600 clone plantation, nutrient retranslocation from the leaves before falling to the soil, and nutrient loss by dry rubber export. The experiment started in 1998 and potassium was applied at the rates of $0,40,80$ and $160 \mathrm{~kg} \mathrm{ha}^{-1}$ of $\mathrm{K}_{2} \mathrm{O}$ under the crowns of 40 rubber trees of each plot. Literfall collectors, five per plot, were randomly distributed within the plots under the trees. The accumulated literfall was collected monthly during one year. The coagulated rubber latex from each plot was weighed, and samples were analyzed for nutrient content. Increasing $\mathrm{K}$ fertilization rates also increased the $\mathrm{K}$ content in leaf literfall. Calcium and $\mathrm{N}$ were the most recycled leaf nutrients to the soil via litterfall. Potassium, followed by $\mathrm{P}$ were the nutrients with the highest retranslocation rates. Potassium was the most exported nutrient by the harvested rubber, and this amount was higher than that transfered to the soil by the leaf literfall.
\end{abstract}

Key words: litterfall, fertilization, nutrition, rubber, nutrient exportation

\section{CICLAGEM DE NUTRIENTES EM UM SERINGAL DO CLONE RRIM 600}

\begin{abstract}
RESUMO: A ciclagem de nutrientes em seringais em fase de produção é assunto pouco estudado. Este trabalho avalia o efeito de doses de potássio nas quantidades de nutrientes que a seringueira (Hevea brasiliensis Muell. Arg.) do clone RRIM 600, com 13 anos de idade, retorna ao solo com a queda natural das folhas, a retranslocação dos nutrientes antes da queda das folhas e a exportação de nutrientes pela borracha seca produzida. O experimento foi instalado em 1998, e as doses de potássio (0, 40, 80 e $\left.160 \mathrm{~kg} \mathrm{ha}^{-1} \mathrm{de} \mathrm{K}_{2} \mathrm{O}\right)$ foram distribuídas sob a copa das 40 seringueiras das parcelas. Cinco coletores de serapilheira foram distribuídos ao acaso sob as árvores em cada parcela. O material vegetal acumulado foi recolhido mensalmente pelo período de um ano. O cernambi produzido em cada parcela foi pesado e em amostra foi determinado o conteúdo de nutrientes. $\mathrm{O}$ aumento das doses de potássio causou aumento no teor deste nutriente nas folhas coletadas na serapilheira. O Ca e o $\mathrm{N}$ são os nutrientes que retornaram em maiores quantidades ao solo com a queda das folhas. $\mathrm{O} \mathrm{K} \mathrm{e} \mathrm{o} \mathrm{P}$ foram os nutrientes que apresentaram a maior taxa de retranslocação. $\mathrm{O} \mathrm{K}$ foi o nutriente mais exportado pela borracha seca, sendo esta quantidade maior que a reciclada ao solo pelas folhas da serapilheira.
\end{abstract}

Palavras-chave: serapilheira, adubação, nutrição, borracha, exportação

\section{INTRODUCTION}

Brazil once was ranked as one of the most important natural rubber exporting countries; the rubber came from native plants located in certain areas of the Amazon plain. However, as years went by, Brazil waned from an exporting position to become dependent on imports of this product. An effort to establish zones for rub- ber cropping demonstrated the potential for rubber production in non-traditional regions such as São Paulo, Minas Gerais, Mato Grosso do Sul and Paraná (Ortolani et al., 1983). The rubber tree is a deciduous plant, and in the State of São Paulo leaf fall occurs in June and July and new leaves emerge in August.

Studies on the mineral nutrition of rubber trees and the correct use of fertilizers have advanced substan- 
tially in the State of São Paulo. Reports by Bataglia et al. (1988, 1998), Falcão (1996), Murbach (1997), Virgens Filho (1998), present the effects of fertilizers on rubber tree development and rubber production. However, studies dealing with nutrient cycling in production-stage rubber plantations still do not exist in São Paulo.

In a rubber plantation the nutrients undergo in a dynamic flow, frequently suffering transformations in a cyclic fashion (Medrado et al., 1991). The heart of nutrient cycling is the soil, which acts as a reservoir and gradually allows the removal and immobilization of nutrients, both by the rubber tree and the plant cover that develops on it (Pushparajah, 1979).

In a 4-year old rubber plantation intercropped with Pueraria phaseoloides (Rio Branco/AC), Haag \& Guerrini (1984) estimated the dry matter of the legume $\left(3,185 \mathrm{~kg} \mathrm{ha}^{-1}\right)$ and of the rubber tree $\left(2,787 \mathrm{~kg} \mathrm{ha}^{-1}\right)$; the later extracting $25 ; 2 ; 18 ; 11$ and $5 \mathrm{~kg} \mathrm{ha}^{-1}$ of $\mathrm{N}, \mathrm{P}, \mathrm{K}, \mathrm{Ca}$ and $\mathrm{Mg}$, respectively. With regard to the amounts of nutrients extracted by the rubber tree and by the legume, $22 \%$ of the K, $37 \%$ of P, $59 \%$ of N, $55 \%$ of $\mathrm{Ca}$ and $54 \%$ of $\mathrm{Mg}$ returned to the soil.

The leaves, branches and seeds that fall from rubber trees make up the main source of nutrients returning to the soil (Medrado et al., 1991). The same authors, quoting data from the literature, stated that production-stage rubber plantations annually drop to the soil 160 and 5,700 $\mathrm{kg} \mathrm{ha}^{-1}$ dry matter as fruits and leaves, respectively, returning to the soil $68 ; 5 ; 15$ and $14 \mathrm{~kg} \mathrm{ha}^{-1} \mathrm{~N}, \mathrm{P}, \mathrm{K}$ and $\mathrm{Mg}$, respectively.

No estimates are available on the return of nutrients to the soil by falling branches for Brazilian rubber plantations, but it is believed that this amount must vary with the clone (Pushparajah, 1979). This author states that rubber tree branches accumulate a large amount of nutrients, so the amount of nutrients that is returned out of falling branches must therefore be significant. For the same author, rainfall can carry to the soil a considerable amount of nutrients contained in the leaves. Annual precipitations around $2,450 \mathrm{~mm}$ are responsible for returning $10 ; 20 ; 0.5$ and $1.5 \mathrm{~kg} \mathrm{ha}^{-1} \mathrm{~N}, \mathrm{~K}, \mathrm{P}$ and $\mathrm{Mg}$ to the soil, from adult plant leaves, respectively.

The objective of this work was to evaluate the effect of potassium fertilization on the amounts of nutrients that return to the soil with the natural leaf shedding from rubber trees. Another objective was to evaluate nutrient retranslocation before leaf fall and nutrient exportation by dry rubber extraction.

\section{MATERIAL AND METHODS}

The assay was carried out at the beginning of November, 1998, in a 13-year old RRIM 600 clone rubber plantation started in 1985, located in Rio Claro, SP, Brazil $\left(22^{\circ} 24^{\prime} 41^{\prime \prime} \mathrm{S}, 47^{\circ} 33^{\prime} 41^{\prime \prime} \mathrm{W}\right)$ with a $7 \mathrm{~m}$ row spacing and
$3 \mathrm{~m}$ between trees. The soil in the experimental area is a Typic Hapludult, sandy texture, with low natural fertility, as indicated by results of the chemical analysis of samples collected before the beginning of the assay, performed according to Raij \& Quaggio (1983). The $\mathrm{pH}$ $\left(\mathrm{CaCl}_{2}\right) \mathrm{pH}$ was 4.6 , the organic matter content was 13.0 $\mathrm{g} \mathrm{dm}^{-3}$, and $\mathrm{P}$ (resin) $6.0 \mathrm{mg} \mathrm{dm}^{-3}$. The $\mathrm{K}, \mathrm{Ca}, \mathrm{Mg}, \mathrm{H}+\mathrm{Al}$, $\mathrm{S}$ and $\mathrm{T}$ values as $\mathrm{mmol}_{\mathrm{c}} \mathrm{dm}^{-3}$ were, respectively, 0.32 ; $5.3 ; 3.0 ; 29.0 ; 8.62$ and 37.62 . V was $23 \%$.

The experimental plot, comprising an area of 840 $\mathrm{m}^{2}$, was made up of 40 plants in 4 rows with 10 plants each. Treatments, arranged in a completely randomized design, consisted of four potassium chloride rates $(0,40$, 80 and $160 \mathrm{~kg} \mathrm{ha}^{-1} \mathrm{~K}_{2} \mathrm{O}$ ) uniformly applied under the tree crown, divided in three identical parts, in November, 1998, January and March, 1999.

In September 1999, five litterfall collectors were placed in each plot, distributed under the tree crowns as recommended by Poggiani (1985); each collector occupied a $1 \mathrm{~m}^{2}$ area. Litterfall from the collectors was gathered monthly, dried and stored, and in August, 2000, when the rubber trees were no longer shedding plant material, all dry matter from leaves in the 5 collectors of each plot was combined and a composite sample was taken for chemical analysis (Sarruge \& Haag, 1974). Based on the global mean amount of dry matter from the 5 collectors in the plot, it was possible to estimate the amounts of litterfall produced per hectare for the different treatments.

In February 2000, samples of 6 month-old leaves were collected from trees in each plot and submitted to chemical analysis according to Sarruge \& Haag (1974). Results from the treatment without potassium were utilized to estimate the nutrient retranslocation rate (TR), by using the formula quoted by Gonçalves et al. (2000).

$$
T R \%=\left(1-\frac{\frac{\mathrm{CND}}{\mathrm{CCD}}}{\frac{\mathrm{CNN}}{\mathrm{CCN}}}\right) \times 100
$$

where: $\mathrm{CND}=$ Mean nutrient concentration in the deciduous tissue, $\mathrm{CCD}=$ Mean $\mathrm{Ca}$ concentration in the deciduous tissue, $\mathrm{CNN}=$ Mean nutrient concentration in normal tissue and $\mathrm{CCN}=$ Mean $\mathrm{Ca}$ concentration in normal tissue. The rubber produced by each plot was weighed and freshly coagulated latex samples were separated, dried at $60^{\circ} \mathrm{C}$, ground and submitted to chemical analysis to determine nutrient contents, following the same methodology used for leaf analysis (Sarruge \& Haag, 1974).

\section{RESULTS AND DISCUSSION}

Regular litterfall is made up of leaves, branches and seeds, but these two last structures were not consid- 
ered for the rubber plantation nutrient cycling study. Falling branches are not uniformly distributed in the rubber plantation, which makes their quantification rather difficult, as it was also observed by Pushparajah (1979).

Potassium rates did not influence the amount of litterfall, which had a dry matter mean of $1,707 \mathrm{~kg} \mathrm{ha}^{-1}$ for all treatments, but increased potassium content of leaves gathered in the collectors from $1.2 \mathrm{~g} \mathrm{~kg}^{-1}$ in the control to $3.6 \mathrm{~g} \mathrm{~kg}^{-1}$ at the $160 \mathrm{~kg} \mathrm{ha}^{-1} \mathrm{~K}_{2} \mathrm{O}$ rate (Figure 1). The low contents of $\mathrm{K}$ in the leaf litterfall can be explained by the fact that part of the $\mathrm{K}$ in the leaves is translocated to the wooden parts of the rubber tree before leaves detach and fall.

The nutrient contents in leaves of fully productive, six-month old rubber trees, in the plant and in the litterfall made up exclusively of leaves that fell in the treatment without potassium, are shown in Table 1. Results were utilized to estimate the retranslocation rate of nutrients before leaf fall, according to Gonçalves et al. (2000). Considering that six-month old leaves yielded, on average, $1,707 \mathrm{~kg} \mathrm{ha}^{-1}$ dry matter in the litterfall, the amount of nutrients in the rubber tree leaves could be estimated (Table 2).

The difference between the amounts of nutrients found in the rubber tree leaves and the amounts of nutrients that were translocated to the wooden parts of the rubber tree theoretically represents the amounts of nutrients in the leaf litterfall (Table 3).

Nutrient translocation has been termed biochemical cycling by Switzer \& Nelson (1972). Among the macronutrients, with the exception of $\mathrm{Ca}$, which is considered immobile, since values in 6-month old leaves and in the litterfall are practically identical (Table 1), all other nutrients undergo biochemical cycling, because their litterfall contents are lower than their contents in 6 monthold leaves. Potassium, followed by phosphorus, are the nutrients with the highest retranslocation rate from the leaves to the wooden parts, followed by nitrogen, magnesium and sulfur. In terms of amounts translocated from the leaves to other parts of the plant, nitrogen is the nutrient that presented the largest values. In the case of magnesium, the amount present in the leaves is in the same order of magnitude as potassium, but since its retranslocation rate is smaller than that of potassium, the translocated amount is also smaller. The amount of sulfur present in the leaves is the smallest of all macronutrients, and it also has the smallest retranslocation rate.

Since the contents of B, Fe and $\mathrm{Mn}$ in the litterfall were larger than in the leaves sampled in February 2000, when they were 6-month old, it was not feasible to apply the retranslocation rate formula suggested by Gonçalves et al. (2000). Deciduous Eucalyptus grandis leaves on average retranslocate $61 \% \mathrm{~N}, 79 \% \mathrm{P}, 50 \% \mathrm{~K}$ and $8 \% \mathrm{Mg}$ to other tree structures, i.e., $50 \mathrm{~kg} \mathrm{~N}^{-1}$ year $^{-1}, 6 \mathrm{~kg} \mathrm{P}^{-1}$ year $^{-1}, 15 \mathrm{~kg} \mathrm{~K} \mathrm{ha}^{-1}$ year $^{-1}$ and only 1 $\mathrm{kg} \mathrm{Mg} \mathrm{ha}{ }^{-1}$ year $^{-1}$, based on a mean leaf deposition of 4.6 $\mathrm{t} \mathrm{ha}^{-1}$ year $^{1}$ (Gonçalves et al., 2000).

The amounts of nutrients that remained in leaves (Table 2) are theoretically the same amounts that should be found in the litterfall. As a matter of fact, when the results of table 3 are compared against data of table 2, it can be observed that the amounts of macronutrients actually deposited on the soil via leaf litterfall, considering that the mean leaf deposition is $1,707 \mathrm{~kg} \mathrm{ha}^{-1}$, are in the

Table 1 - Nutrient contents in control tree leaves.

\begin{tabular}{|c|c|c|c|c|c|c|c|c|c|c|c|}
\hline Sample $^{1}$ & $\mathrm{~N}$ & $\mathrm{P}$ & $\mathrm{K}$ & $\mathrm{Ca}$ & $\mathrm{Mg}$ & $\mathrm{S}$ & B & $\mathrm{Cu}$ & $\mathrm{Fe}$ & $\mathrm{Mn}$ & $\mathrm{Zn}$ \\
\hline & $\ldots$ & $\cdots$ & $\cdots$ & $1 \ldots$ & $\cdots$ & - - & $-\cdots$ & $-\cdots$ & $\mathrm{g} \mathrm{kg}^{-1}$ & -... & $-\cdots$ \\
\hline A & 33.1 & 3.6 & 8.3 & 25.0 & 6.8 & 2.8 & 36 & 12 & 271 & 130 & 25 \\
\hline $\mathrm{B}$ & 13.1 & 0.9 & 1.1 & 24.0 & 4.8 & 2.4 & 54 & 9 & 554 & 170 & 16 \\
\hline
\end{tabular}

${ }^{1}$ Sample A: 6-month old rubber tree leaves. Sample B: rubber tree leaves collected from litterfall.

Table 2 - Estimates of amounts of nutrients in 6-month old rubber tree leaves, macronutrient retranslocation rates, amounts of nutrients remaining and translocated.

\begin{tabular}{|c|c|c|c|c|c|}
\hline Estimate & $\mathrm{N}$ & $\mathrm{P}$ & $\mathrm{K}$ & $\mathrm{Mg}$ & $\mathrm{S}$ \\
\hline Nutrients in rubber tree leaves before falling $\left(\mathrm{kg} \mathrm{ha}^{-1}\right)$ & 56.5 & 6.1 & 14.2 & 11.7 & 4.8 \\
\hline Retranslocation rate $(\%)$ & 59 & 73 & 86 & 27 & 9 \\
\hline Amounts of nutrients translocated from leaves $\left(\mathrm{kg} \mathrm{ha}^{-1}\right)$ & 33.3 & 4.5 & 12.2 & 3.2 & 0.4 \\
\hline Amounts of nutrients remaining in the leaves $\left(\mathrm{kg} \mathrm{ha}^{-1}\right)$ & 23.2 & 1.6 & 2.0 & 8.5 & 4.4 \\
\hline
\end{tabular}

Table 3 - Estimate of amounts of nutrients that actually return to the soil in a 15-year old rubber plantation, considering an annual litterfall deposition of $1,707 \mathrm{~kg} \mathrm{ha}^{-1}$ leaf dry matter.

\begin{tabular}{|c|c|c|c|c|c|c|c|c|c|}
\hline $\mathrm{N}$ & $\mathrm{P}$ & $\mathrm{K}$ & $\mathrm{Ca}$ & $\mathrm{Mg}$ & $S$ & B & $\mathrm{Cu}$ & $\mathrm{Fe}$ & $\mathrm{Mn}$ \\
\hline & -..- & $-\cdots$ & $\mathrm{g} \mathrm{ha}^{-1}$ & $\ldots$ & - & \multicolumn{4}{|c|}{ - $\mathrm{g} \mathrm{ha}^{-1}$ year $^{-1} \ldots \ldots \ldots$} \\
\hline 22.4 & 1.5 & 1.9 & 41.0 & 8.2 & 4.1 & 93 & 16 & 946 & 291 \\
\hline
\end{tabular}


Table 4 - Nutrient contents in dry rubber produced in plot without potassium and amount exported per 1,700 $\mathrm{kg} \mathrm{ha}^{-1} \mathrm{dry}$ rubber.

\begin{tabular}{|c|c|c|c|c|c|c|c|c|c|}
\hline $\mathrm{N}$ & $\mathrm{P}$ & $\mathrm{K}$ & $\mathrm{Ca}$ & $\mathrm{Mg}$ & $S$ & $\mathrm{Cu}$ & $\mathrm{Fe}$ & $\mathrm{Mn}$ & $\mathrm{Zn}$ \\
\hline \multicolumn{6}{|c|}{ - } & \multicolumn{4}{|c|}{ - } \\
\hline 2.80 & 1.09 & 2.95 & 0.84 & 0.21 & 0.22 & 5 & 133 & 395 & 31 \\
\hline \multicolumn{10}{|c|}{-1} \\
\hline 4.8 & 1.9 & 5.0 & 1.4 & 0.4 & 0.4 & 9 & 226 & 672 & 53 \\
\hline
\end{tabular}

same order of magnitude. Therefore, the formula for calculating retranslocation rate is valid in the case of macronutrients.

Calcium and nitrogen are the nutrients returning to the soil by the largest amounts. Results like these were also obtained by Shorrocks (1965) while evaluating the amounts of nutrients that return to the soil through natural leaf shedding in adult rubber plantations of Malaysia, but he stated that the amount of calcium returning to the soil surpasses the amounts of the other nutrients only when the soil shows a high content of available calcium during the leaf renovation period. The same author estimated N, P, K and Ca to return to the soil in the following amounts, respectively: 45 to 90,3 to 7,10 to 20 and 60 to $120 \mathrm{~kg} \mathrm{ha}^{-1}$.

In the more specific case of potassium, considering the contents found in leaf litterfall of treatments with increasing rates of this nutrient, and the amount of leaf litterfall on average being $1,707 \mathrm{~kg} \mathrm{ha}^{-1}$, the amount recycled could reach $7 \mathrm{~kg} \mathrm{ha}^{-1}$ year $^{-1}$, considering a retranslocation rate of $86 \%$. This is a much lower value than the amount of potassium applied to the soil, even at the smallest rate of the present experiment, but it could lead to soil depletion if potassium fertilization is not performed in rubber plantations. This observation, in a sense, agrees with the work by Vitousek (1984) who, based on the concentration of nutrients found in freshly fallen leaves from different forests around the world, suggested nitrogen to be the most limiting element in temperate climate forests, and phosphorus as the most limiting element in tropical forests.

Potassium rates did not change the potassium content in the coagulated latex. The mean nutrient contents found in the freshly coagulated latex are shown in Table 4. Rubber, when commercialized in the form of coagulated latex, exported the amounts of nutrients shown in table 4 , since the production of dry rubber in the control treatment was $1,700 \mathrm{~kg} \mathrm{ha}^{-1}$ for the cropping season under study. The amounts of nitrogen, calcium, magnesium, sulfur, copper and iron exported from the rubber plantation by rubber extraction are much smaller than the amounts of nutrients deposited on the soil by natural leaf shedding from rubber trees. With respect to phosphorus, the amounts recycled by litterfall and exported by the rubber are of the same order of magnitude. For potassium, amount exported by the rubber was larger than the amount recycled by litterfall, in the plot without application of this nutrient. Considering the same potassium retranslocation rate from the leaves to the wooden parts, the dry matter content in the litterfall necessary to recycle $5 \mathrm{~kg}$ of potassium should be $2.9 \mathrm{~g} \mathrm{~kg}^{-1}$, a value that would be attained by fertilization with approximately $135 \mathrm{~kg} \mathrm{ha}^{-1}$ $\mathrm{K}_{2} \mathrm{O}$, as calculated by Figure 1, an amount more than twice as high as the rate recommended by Bataglia \& Gonçalves (1997) for the soil of the experiment. Potassium is a nutrient that has had an effect on rubber tree development and on rubber production in plantations in the state of São Paulo. For example, Murbach et al. (1999), while evaluating the effect of NPK fertilization on rubber production, observed that potassium fertilization had a positive effect on yield, which did not occur with nitrogen and phosphate fertilization.

Special attention should be given to productionstage rubber plantations, since they present two important drains (Pushparajah, 1977). The first drain draws off nutrients for the vegetative growth of roots, trunk, branches and fruit. The second draws, off nutrients for latex production.

\section{CONCLUSIONS}

As potassium rates in the soil increase, the content of this nutrient in the leaves collected from litterfall also increases. Calcium and nitrogen are the nutrients more intensely returned to the soil with leaf litterfall. Potassium, followed by $\mathrm{P}$, are the nutrients showing the largest retranslocation rates. For a dry rubber productivity of $1700 \mathrm{~kg} \mathrm{ha}^{-1}$, rubber trees export, per year, 5; 2 and $5 \mathrm{Kg}$ $\mathrm{N}, \mathrm{P}$ and $\mathrm{K}$, respectively.

\section{ACKNOWLEDGEMENTS}

To FAPESP for financial support and for a scholarship offered to the first author; and to Fazenda São José for providing the experimentation area.

\section{REFERENCES}

BATAGLIA, O.C.; GONÇALVES, P.S. Seringueira. In: RAIJ, B.; CANTARELlA, H.; QUAGGIO, J.A.; FURLANI, A.M.C. (Ed.) Recomendações de adubação e calagem para o estado de São Paulo. Campinas: Instituto Agronômico; Fundação IAC, 1997. p.243. (Boletim Técnico 100) 
BATAGLiA, O.C.; CARDOSO, M.; CARRETERO, M.V. Situação nutricional de seringais produtivos no estado de São Paulo. Bragantia, v.47, p.109-123, 1988.

BATAGLIA, O.C.; SANTOS, W.R.; IGUE, T.; GONÇALVES, P.S. Resposta da seringueira clone RRIM 600 à adubação NPK em solo Podzólico Vermelho Amarelo. Bragantia, v.57, p.367-377, 1998.

FALCÃO, N.S.F. Adubação NPK afetando o desenvolvimento do caule da seringueira e parâmetros fisiologicos do látex. Piracicaba: USP/ESALQ, 1996. 134p. (Tese - Doutorado)

GONÇALVES, J.L.M.; STAPE, J.L.; BENEDETTI, V.; FESSEL, V.A.G.; GAVA, J.L. Reflexos do cultivo mínimo e intensivo do solo em sua fertilidade e na nutrição das árvores. In: GONÇALVES, J.L.M.; BENEDETTI, V. Nutrição e fertilização florestal. Piracicaba: IPEF, 2000. cap.1, p.1-57.

HAAG, H.P.; GUERRINI, I.A. Nutrição mineral da seringueira: III. Ciclagem de nutrientes em um seringal na região de Rio Branco, Acre. Anais da ESALQ, v.41, p.277-291, 1984.

MEDRADO, M.J.S.; COSTA, J.D.; FONSECA FILHO, H.; BERNARDES, M.S.; DURAES, F. Ciclagem de nutrientes em seringais de cultivo. Universitário de Agronomia, v.2, p.19-21, 1991.

MURBACH, M.R. Efeitos da adubação NPK no crescimento, na produtividade e na exportação de nutrientes pela seringueira. Piracicaba: USP/ESALQ, 1997. 91p. (Dissertação - Mestrado)

MURBACH, M.R.; BOARETTO, A.E.; MURAOKA, T.; SILVEIRA, R.I.; BOARETTO, R.M. Adubação NPK e produção de borracha seca pela seringueira (Hevea brasiliensis) Scientia Agricola, v.56, p.71-76, 1999.

ORTOLANI, A.A.; PEDRO JR., M.J.; ALFONSI, R.R.; CAMARGO, N.B.D.; BRUNINI, O. Aptidão agroclimática para regionalização da heveicultura no Brasil. In: SEMINÁRIO BRASILEIRO SOBRE RECOMENDAÇÕES DE CLONES DE SERINGUEIRA, 1., Brasília, 1983. Anais. Brasília: SUDHEVEA, 1983. p.19-28.
POGGIANI, F. Ciclagem de nutrientes em ecossistemas de plantações florestais de Eucalyptus e Pinnus. Implicações silviculturais. Piracicaba: USP/ESALQ, 1985. 121p. (Tese - Livre-Docência)

PUSHPARAJAH, E. Nutritional status and fertilizer requirements of Malaysia on soil for Hevea brasiliensis. Chent State: University of Ghent Belgium,1977. 275p. (Thesis - D.S.)

PUSHPARAJAH, E. Nutrient cycle in rubber plantations. In: RUBBER RESEARCH INSTITUTE OF MALAYSIA. Training manual on soil, soil management and nutrition of Hevea. Kuala Lumpur: RRIM, 1979. p.88-97.

RAIJ, B.; QUAGGIO, J.A. Métodos de análises de solos para fins de fertilidade do solo. Campinas: Instituto Agronômico, 1983. 31p. (Boletim Técnico, 81).

SARRUGE, J.R.; HAAG, H.P. Análises químicas em plantas. Piracicaba: USP/ESALQ - Depto. de Química, 1974. 56p.

SHORROCKS, V.M. Mineral nutrition: growth and nutrient cycle of Hevea brasiliensis: II- Nutrient cycle and fertilizer requirements. Journal of the Rubber Research Institute of Malasya, v.19, p.48-61, 1965.

SWITZER, G.L.; NELSON, L.E. Nutrient accumulation and cycling in Loblolly Pine (Pinus taeda) plantation ecosystems: The first 20 years. Soil Science Society of America Proceedings, v.36, p.143-147, 1972.

VIRGENS FILHO, A.C. Calagem, adubação e explotação da seringueira, cultivar RRIM 600, em Latossolo Amarelo álico, no planalto do estado de São Paulo. Piracicaba: USP/ESALQ, 1998. 91p. (Tese - Doutorado)

VITOUSEK, P.M. Litterfall, nutrient cycling, and nutrient limitation in tropical forest. Ecology, v.65, p.285-298, 1984.

$\overline{\text { Received February }}$ 28, 2002 